\section{Investigation of summarization skills of primary school students}

\section{İlkokul öğrencilerinin özetleme becerilerinin incelenmesi}

\author{
Yasemin Kuşdemir ${ }^{1}$ \\ Ceren Meral Düşünsel ${ }^{2}$ \\ Mücahit Çelik ${ }^{3}$
}

\begin{abstract}
In order to understand a text or a book better and enhance the comprehension skills, a great number of strategies and methods is used in the process of reading. One of these is summarizing strategy that is employed after reading. Summarizing is the creation of a text corresponding to the original text on a small scale as its shorter form, by keeping the main theme and content of a text and through excluding less important information and details. The objective of this research made is to analyze the primary school fourth-grade students' summarizing skills. Summarizing skills have been analyzed in accordance with the subtitles that are shortening the outlined text and identifying the essential information, and writing title for the text summarized. The research was carried out with the participation of 247 students, in the center of Kurikkale province in the academic year 2016-2017. Within the scope of study, "Interview Form Related to Summarization for the Primary School 4th-Grade Students", "Summarizing Strategies Scoring Scale" and a narrative text have been used. 173 of students participated in the research have stated that they like both reading and writing; 40 of them have expressed that they prefer to read books mostly and 16 of
\end{abstract}

Özet

Bir metni veya kitabı daha iyi anlamak, anlama becerilerini geliştirmek için okuma sürecinde pek çok strateji ve yöntem kullanılmaktadır. Bunlardan biri de okuma sonrasinda kullanilan özetleme stratejisidir. Özetleme, bir metnin ana fikrini ve muhtevasinı koruyarak, daha az önemli olan bilgi ve ayrıntıların çıkarılması yoluyla asıl metinden daha kısa olan küçük ölçekte bir benzeri olan bir metnin oluşturulmasıdır. Yapılan bu araştırmanın amacı ilkokul dördüncü sinıf öğrencilerinin özetlemeye ilişkin becerilerin incelenmesidir. Özetleme becerileri, özetlenen metni kisaltma ve önemli bilgileri belirleme ile yazılan özete başlık yazma alt başlıklarına göre analiz edilmiştir. Araştırma 2016-2017 eğitim-öğretim yllında Kırıkkale il merkezinde 247 öğrencinin katılımıyla gerçekleştirilmiştir. Araştırmada veri toplamak için "İlkokul Dördüncü Sınıf Öğrencileri İçin Özetlemeye Yönelik Görüşme Formu", "Özetleme Stratejileri Puanlama Ölçeği" ve hikâye edici bir metin kullanılmıştır. Araştırmaya katılan öğrencilerin 173 'ü hem okumayı hem de yazı yazmayı sevdiğini; 40'1 kitap okumay1, 16's1 ise yazı yazmayı daha çok tercih ettiğini belirtmiştir. Araştırma sonuçların göre bu öğrencilerden 116'sının sinıf öğretmeni kadın; 130'unun sınıf öğretmeni ise erkektir.

\footnotetext{
${ }^{1}$ Dr., Kırıkkale Üniversitesi Eğitim Fakültesi Temel Eğitim Bölümü, yaseminkusdemir@kku.edu.tr

2 Kırıkkale Üniversitesi, Sosyal Bilimler Enstitürü, c meral dusunsel@hotmail.com

${ }^{3}$ Kurıkkale Üniversitesi, Sosyal Bilimler Enstitürü, mucahit025@gmail.com
} 
them had rather to write. According to the research results, 116 of these students have a female classroom teacher and for 130 of them, their classroom teacher is male. The average scores pertaining to the variables for students to be able to write the summary of narrative texts, write a suitable title for the summary, distinguish essential information and make reductions in the summarized texts are at low level. Students' summarizing skills differ significantly according to gender and female students are understood to be more successful than male ones. When considered the variable of teacher's gender, it is understood that the students whose classroom teacher is male are more successful in writing a summary. Additionally, a significant relation between the scores for students' being able to write summary and student gender and teacher gender has been found out. When the scores for students' being able to write a title for the summary text which they have already written is analyzed, it has been determined that the averages of writing title for the students who have learnt how to summarize from their parents or friends are higher than the general average.

Keywords: Summarizion; Reading; Reading Comprehension Strategy.

(Extended English summary is at the end of this document)
Öğrencilerin hikâye edici metinlerin özetini yazabilme, özete başlık yazabilme, önemli bilgileri seçebilme ve özet metinlerde kısaltma yapabilme değisskenlerine ait ortalama puanları düşük seviyededir. Öğrencilerinin özet yazabilme becerileri cinsiyete göre anlamlı farklılık göstermektedir ve kızların erkeklere göre daha başarılı olduğu anlaşılmaktadır. Öğretmen cinsiyeti değişkeni dikkate alındığında, sınıf öğretmeni erkek olan öğrencilerin özet yazmada daha başarılı olduğu anlaşılmaktadır. Ayrıca, öğrencilerin özet yazabilme puanları ile öğrenci cinsiyeti ve ögretmen cinsiyeti arasında anlamlı bir ilişki bulunmuştur. Öğrencilerin yazdıkları özet metne başlık yazabilme puanları incelendiğinde, özet yazmayı anne-babalarından veya arkadaşlarından öğrenen öğrencilerin başlık yazabilme ortalamalarının genel ortalamadan yüksek olduğu belirlenmiştir.

Anahtar Kelimeler: Özetleme; Okuma; Okuduğunu Anlama Stratejisi.

\section{Giriş}

Okuma, insan hayatında önemli etkileri olan bir dil becerisidir. İyi bir okuma becerisine sahip olmak bireye akademik başarı, kaliteli iletişim, farklı kültür ve fikirlere yönelik geniş bakış açısı kazandırabilmektedir. Teknik gelişmelere paralel olarak okuma araçları (dijital araçlar - basılı kitaplar) çeşitlense de okumanın kendisi bilgiye ulaşma yolları arasındaki önceliğini korumaktadır. Bağımsız bir okur-yazar olabilmek için bilgiye ulaşmış olmak da aslında tek başına yeterli değildir. Metindeki anlamı kavrayabilmek ve özü yakalayabilmek, elde edilen bilgiyi kullanabilmek, tecrübe ve gözlemlerle anlamı zihinde yapılandırarak dönüştürüp yeni ve özgün fikirler üretebilmek asıl gayedir. Bunu gerçekleştirebilmek için okuyucunun metinle (/kitapla) olan meşguliyeti bir takım teknik ve araçların kullanımını gerektirmektir. Bu bakış açısı, okuduğunu anlama sürecini sıradan bir okuma alışkanlığı yahut boş zamanlarda kitap okuma eylemi olmaktan da uzaklaştırmaktadır. Yetkin bir okur olmak okuduğunu anlamak için okumanın başından sonuna kadar zihinsel emek harcamay1 beraberinde getirmektedir.

Okuma, zihinsel ve psiko-motor becerilerin birlikte hareket etmesiyle yazıdan anlam çıkarma etkinliği, yazının anlamlı bir hale gelmesidir (Sever, 2004: 11).Okuma bilinci gelişmiş olan birey, neyi, nasıl ve ne zaman okuması gerektiğinin farkına varır, okuma becerisinin yaşama dair bir değer taşıdığını bilir ve bu beceriyi hayatının bir parçası haline getirir. Diğer yandan okuma 
Kuşdemir, Y., Düşünsel, C. M., \& Çelik, M. (2018). İlkokul öğrencilerinin özetleme becerilerinin incelenmesi. Journal of Human Sciences, 15(2), 893-910. doi:10.14687/ihs.v15i2.5208

becerisi, konuşma ve dinleme becerileri gibi kendiliğinden gelişmez, bir eğitim süreci gerektirir (Güneyli, 2003: 32). Okuduğunu anlama süreci, yazılı metinleri anlamayı, yorumlamayı ve metinlerdeki anlamı metin türüne, amaca ve duruma uygun kullanmayı içeren aktif ve karmaşık bir süreç olarak ifade edilmektedir (Ertem, 2014: 52). İyi okuyucuların okuma sürecinde, okuduğunu anlama strateji ve tekniklerini kullandıkları bilinmektedir. Yapılan araştırmalarda (Batmaz, 2017; Aktaş, 2015; Yılmaz ve Top, 2015; Gürbüz, 2014; Sulak, 2014; Bozpolat, 2012; Kanmaz, 2012; Ayçin, 2009; Çakıroğlu, 2007; Pilten, 2007) anlama stratejilerini öğrenmenin ve kullanmanın okuduğunu anlama düzeyini olumlu yönde etkilediği belirlenmiştir. Okuma eğitiminin temel hedefi de aslında okuduğunu anlama becerilerini geliştirebilmektir. Anlama kabiliyetinin gelişmesi belirli stratejileri bilme, öğrenme ve kullanmayı gerektirmektedir ki esasen bu "yetkin okur" olmanın da temel dayanağı olmaktadır. Metni okuyan kişi, ana fikri bulmak, konuya hâkim olabilmek ve yazarın açık veya örtülü niyetini kavrayabilmek için strateji ve teknikleri kullanmalı, bazı etkinlikleri gerçekleştirmelidir. İlkokuldan başlayarak pek çok eğitim kademesinde verilen okuma eğitimi, okuduğunu anlama stratejilerinin-tekniklerinin öğretimini ve kullanılmasını kapsamalıdır. Özellikle küçük yaşlardan itibaren öğrencilere bir metni okurken neler yapmaları gerektiğinin öğretilmesi ustalaşmış/maharetli okuyucular olmasına hizmet edecektir. Okuma eğitimi alan bireyin metni seslendirmenin yanında anlama içinde gayret etme bilincini kazanması mühimdir. Anlama, okuma anında metin ve metinle ilgili yapılacak işlemlerin bilinmesiyle yakından ilişkilidir.

İyi bir okuyucu okuma öncesinde bir amaca sabiptir, metni gözden geçirir, ana hatlaryla tarar, metinde nelerden söz. edildiği hakekinda hipotezler ileri sürer. Okuma esnasinda metni baștan sona kadar okur. Bazen okumalarm tekrarlayabilir, okuduğu metinle ilgili notlar alabilir, okuduklarryla ileri sürdüğ̈ tahminlerini kontrol eder. Metinle ilgili özetlemeler yapar, metinde ileri sürülen düsünceleri araștırr, kendi ön bilgileriyle karşılaştırı, yazarla kendi düsünceleri arasında kritikler, çözümlemeler, yorumlamalar yapar (Epçaçan ve Erzen, 2010: 23)

Okuma esnasında, sürece dâhil olan unsurlar Şekil 1'de sunulmuştur (Fox ve Alexander, 2009: 228; Sweet ve Snow, 2002; Reutzel ve Cooter, 2009: 154; Akt: Kuşdemir, 2014):

\section{Şekil 1: Okuduğunu anlama sürecinin temel unsurları}

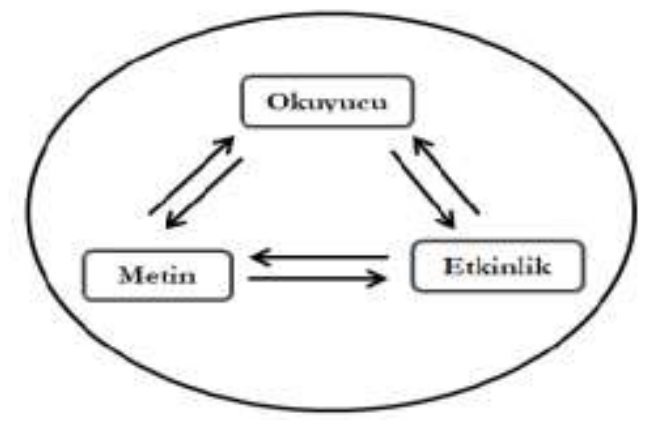

Şekil 1'de belirtilen ve okuma sürecinde uygulanabilecek etkinlikler genel olarak aşağıdaki gibi sınıflandırılmaktadır (Akyol, 2012: 35-53):

1- Okuma Öncesi Etkinlikler:

a) Göz gezdirme

b) Okuma için amaç belirleme

c) Ön bilgileri kullanma

d) Görsel öğeler ve başlıklardan hareketle, metnin içeriğine ilişkin tahminlerde bulunarak beyin firtınasi yapma

2- Okuma Sirasinda Yapılabilecek Etkinlikler:

a) Akıcı bir şekilde okuma

b) Anlamay1 kontrol etme

c) Ana stratejileri destekleyecek yardımcı stratejileri kullanma 
Kuşdemir, Y., Düşünsel, C. M., \& Çelik, M. (2018). İlkokul öğrencilerinin özetleme becerilerinin incelenmesi. Journal of Human Sciences, 15(2), 893-910. doi:10.14687/ihs.v15i2.5208

\section{3- Okuma Sonrasinda Yapulabilecek Etkinlikler:}

a) Özet çıkarma

c) Değerlendirmeler yapma

Okuma sonrasında anlama düzeyini geliştirmek üzere kullanılan stratejilerden ve etkinliklerden biri de özetlemedir. Okunan metnin anlamından kopmadan kısaltılmasını ifade eden özetlemenin okuyucuya pek çok yararı vardır. Hem öğretmene hem de öğrenciye olumlu katkılar sunan özetleme öğrenciye ana fikri fark etme, kendi anlama düzeyini kontrol etme, karar verme ve sıralama imkânı sağlamaktadır. Özetleme, öğretmene de öğrencisinin metindeki önemli bilgileri seçme ve anlama kabiliyeti hakkında deliller sağlayabilmektedir (Westby, Culatta, Lawrence, Hall-Kenyon, 2010: 276). Öğrencilere okuduklarını ve düşündüklerini metnin içeriğiyle tutarlı hale getirme firsatı veren özetleme aynı zamanda yazılı anlatımın-özetlemenin gerektirdiği bir dizi kural ve ilkenin kullanımına ilişkin geri bildirim (Beydoğan, 2010: 15) sunmaktadır.

Aslinda, konuyla ilgili deneyim sabibi birçok kiși özetlemenin çocuklar için çok zor olduğu konusunda bem

fikirdirler. Cocuklar çoğunlukla metinlerin güzel ve iyi yazllmıs özetlerini üretebilmek için pratiğe ve yönlendirilmeye ibtiyac duymaktadır. İlginctir, araştrmalar özetlerken ögretim ve uygulamanin yalmąca ögrencilerin metni özetleme becerisini gelistirdiğini değil, ayn zamanda metin içeriğini genel olarak anlamalarm gelistirdiğini ileri sürmektedir. Böylece, özetleme eğitimi, ögrencilerin hem metni özetleyebilme yeteneklerini gelistirme hem de metinleri anlama ve hatırlama yeteneklerini ilerletme amaçlarm karşılamaktadır (Duke \&

Pearson, 2008: 221).

Özetleme çalışmalarında öğrencinin kaynak metni anlaması yapılandırılacak yeni metnin de esasını oluşturur. Bu nedenle özetleme eğitiminde öncelikli olarak üzerinde durulması gereken nokta anlama çalışmalarıdır. Metni anlama, kaynak metindeki kodların çözümü ve zihinde bir dizi işlem sonras1 yapılandırılması ile mümkündür (Erdem, 2012: 39). İyi bir özet metin nasıl olmalıdır? Öncelikle özet yazmadan önce özetlenecek metnin ana fikrinin doğru anlaşılması gerekmektedir. Konunun ne olduğu belirlenmeli, ana fikir bir cümle ile ifade edilmelidir. Okuyucunun metnin türü hakkında fikir sahibi olması da özetleme işini kolaylaştırabilir. Metin türü hakkında doğru karar vermek okuyucuya metin yapısı ve ayrıntılarla ilgili çalışma firsatı sağlar. Özellikle önemsiz bilgiler ve tekrarlanan ayrıntılar ile okuyucunun yorumları/fikirleri özet metinde bulunmamalıdır. Bulut (2006) tarafından özetlemeye yönelik geliştirilen ölçekte özetleme ölçütleri şu şekilde belirlenmiştir:

1. Özete uygun bashlk yazmak,

2. Yaziyn kâğt yüzeyine uygun bir biçimde yerleştirmek,

3. Noktalama ișaretlerine ve imlâya dikekat etmek,

4. Özetlemede paragraf yapmak,

5. Konuy a bağh kalmak,

6. Kendi kelime ve cümlelerini kullanmak,

7. Özeti orijinal metinden kisa olmak,

8. Yardima fikirlere yer vermis olmak,

9. Özete ana fikri yazmis olmak,

10. Özeti konunun akessina uygun yazms olmak.

Özet metnin okuyucunun kendi cümleleri ile yazılması da önemli bir husustur. O halde yazar tarafından yazılan uzun cümleler anlamı kaybetmeden nasıl kısaltılabilir? "Bir cümleyi özetlemek için, cümle içindeki gereksiz kelimeleri çıkarılmalıdır. Aynı anlama gelen cümle gruplarının yerine eş anlamlı bir özet kelimesi kullanılabilir. Bu aşamada sadece cümlenin ana fikrini ifade eden ana kelimeleri kullanmak yeterlidir. Mümkün olduğu kadar az kelime (Mikulecky ve Jeffries, 1996: 167) ile cümle veya paragrafın anlamı verilmeye çalışlmalıdır. Özetlemeyi yeni öğrenenlerin ve derslerde akademik görevleri yerine getirmek için özet yazan öğrencilerin özet çıkarırken karşılaştıkları zorluklar sıralandığında (Kelley ve Grace, 2007: 156) aşağıdaki liste oluşmaktadır:

- Onemli olan dâhil etmiyorlar.

- Neyin önemli olduğunu bilmiyorlar.

- Cok fazla bilgiyi dâbil ediyor, özetlemek yerine yeniden anlatiyorlar.

- Yeteri kadar bilgiyi dâbil etmiyorlar.

- "Kendi cümlelerini" nasıl kullanacaklarm bilmeyip metni kopyalyyorlar. 
- Ana fikri ya da destekleyici ayrnttlar atllyorlar.

Özet çıkarma veya özetleme işi okunan ya da dinlenen metinlerin daha iyi anlaşılmasına, anlaşılanların zihinde yapılandırılarak kalıcılığının sağlanmasına yardımcı olabilir (Göçer, 2014: 177). Bu özellikler dikkate alındığında özet yazmanın anlama, hatırlama, tasnif, karşılaştırma ve bunlara ek olarak anlamlı metin oluşturma gibi becerilerin geliştirilmesine hizmet ettiği belirtilebilir.

\section{Araştırmanın Amacı}

$\mathrm{Bu}$ araştırmanın amacı ilkokul dördüncü sınıf öğrencilerinin okuduğunu anlamanın bir bileşeni olarak özetlemeye ilişkin becerilerinin incelenmesidir. Araştırmada aşağıdaki sorulara cevap aranmiştır:

1-İlkokul dördüncü sınıf öğrencilerinin hikaye edici metinleri özetleyebilme durumları nedir?

2-İlkokul dördüncü sınıf öğrencilerinin hikaye edici metinleri özetleyebilme durumları

a.Cinsiyete göre;

b.Öğretmenin cinsiyetine göre;

c. Okul veya öğretmen değiştirme durumuna göre;

d.Okuma veya yazma tercih durumlarına göre;

e.Yazılan özetin kontrol edilme durumuna göre;

f.Özet yazma siklı̆̆ına göre;

g.Özetlemeyi kimden öğrendiğine göre

h.Özet yazarken zorlanma durumuna göre anlamlı farkll1ık göstermekte midir?

\section{Yöntem}

Bu bölümde araştırmanın modeli, evren-örneklem, veri toplama aracı, verilerin toplanması ve çözümlenmesi hakkında bilgi verilmektedir.

\subsection{Araştırma Modeli}

Kırıkkale il merkezindeki devlet okullarında dördüncü sınıfa devam eden öğrencilerinin özetleme becerilerini incelemeyi amaçlayan bu araştırmada betimsel model kullanılmıştır.

\subsection{Evren ve Örneklem}

Araştırmanın evrenini Kırıkkale il merkezindeki ilkokullarda öğrenimlerine devam eden dördüncü sınıf öğrencileri oluşturmaktadır. Evreni temsil edecek olan örneklem grubunun belirlenmesinde şu adımlar izlenmiştir: Öncelikle Kırıkkale İl Milli Eğitim Müdürlüğünden il merkezindeki ilkokulların sayısı, bu okullardaki sınıf sayısı ve öğrenci dağılımının belirtildiği liste alınmıştır. Bu listeye göre 2016-2017 eğitim-öğretim yılında Kırıkkale il merkezindeki 39 ilkokulda 3702 dördüncü sınıf öğrencisi öğrenim görmektedir. Araştırmanın örneklem seçiminde uygun örnekleme yöntemi kullanılmıştır. Uygun örnekleme yöntemi kullanılmasının gerekçesi, araştırmacının maliyet, zaman, kolay erişilebilirlik gibi etkenlerin de göz önüne alınmış olmasıdır. Araştırmanın örneklemi, Cohen, Manion ve Morrison (2007) tarafindan belirtilen \%90 güvenilirlik düzeyinde 5000 ve üzerinde 258 olması gereken sayı ölçütü alınarak belirlenmiştir. Buna göre 285 ilkokul dördüncü sınıf öğrencisine ulaşılmış olmasına rağmen yazıların okunamaması, veri toplama aracındaki maddelerin çoğunluğunun boş bırakılması veya verilen cevapların değerlendirmeye alınamayacak nitelikte olması sebebiyle 247 öğrencinin doldurduğu veri toplama aracı işleme alınmıştır. 
Kuşdemir, Y., Düşünsel, C. M., \& Çelik, M. (2018). İlkokul öğrencilerinin özetleme becerilerinin incelenmesi. Journal of Human Sciences, 15(2), 893-910. doi:10.14687/jhs.v15i2.5208

Tablo 1. Örneklem ile ilgili genel bilgiler

\begin{tabular}{|c|c|c|c|c|c|c|c|c|c|}
\hline \multicolumn{2}{|c|}{$\begin{array}{l}\text { Öğrencilerin } \\
\text { Cinsiyeti }\end{array}$} & \multicolumn{2}{|c|}{$\begin{array}{c}\text { Araştırmaya } \\
\text { Katılan } \\
\text { Öğrencilerin } \\
\text { Öğgetmenlerinin } \\
\text { Cinsiyeti }\end{array}$} & \multicolumn{2}{|c|}{$\begin{array}{c}\text { Öğrencilerin } \\
\text { Öğretmen (Okul) } \\
\text { Değişimi }\end{array}$} & \multicolumn{4}{|c|}{$\begin{array}{c}\text { Öğrencilerin } \\
\text { Okuma-Yazma Tercihleri }\end{array}$} \\
\hline $\mathrm{K}_{12}$ & Erkek & Kadın & Erkek & Değişti & Değişmedi & $\begin{array}{l}\text { Kitap } \\
\text { Okuma }\end{array}$ & Yazma & $\begin{array}{c}\text { Kitap } \\
\text { Okuma- } \\
\text { Yazma }\end{array}$ & Hiçbiri \\
\hline 132 & 115 & 116 & 130 & 137 & 101 & 40 & 16 & 173 & 17 \\
\hline \multicolumn{2}{|c|}{ Genel Toplam } & 247 & & & & & & & \\
\hline
\end{tabular}

\subsection{Veri Toplama Araçları}

Verileri toplamak için araştırmacılar tarafından geliştirilen "Illkokul Dördüncü Sını Öğgrencileri İcin Özetlemeye Yönelike Görüsme Formu” ve çalışmaya katılan öğrencilerin yazdıkları özet metinler doküman olarak kullanılmıştır. Özet metinlerin incelenmesi ve puanlanması "Özetleme Stratejileri Puanlama Ölçĕgi” ile yapılmıștır.

İlkokul Dördüncü Sınıf Öğrencileri İçin Özetlemeye Yönelik Görüşme Formu: Formu üç bölümden oluşmaktadır. Birinci bölümde öğrencileri tanımaya yönelik sorular bulunmaktadır: öğrencinin cinsiyeti, sınıf öğretmeninin cinsiyeti, öğrencinin okul veya sınıf değiştirme durumu ve öğrencinin okuma veya yazma tercihi sorularıdır. İkinci bölümde, öğrencilerin özet yazma ve öğrenme süreciyle ilgili görüsslerine yönelik sorular bulunmaktadır. Üçüncü bölümde öğrencilerin okuyup özetlemeleri için hikâye edici bir metin vardır.

Özetleme Stratejileri Puanlama Ölçeği: Özçakmak (2015) tarafindan geliştirilen bu ölçekte özetleme stratejileri ana başlığ altında 8 alt başlık bulunmaktadır. Bu ölçekten alınabilecek toplam puan 100'dür:
- Baslle yazma
- Bakıs açsim doğru kullanma,
- Önemli bilgiyi seçme
- Önemsiz bilgizi silme,
- Metin disı bilgive yer vermeme,
- Tutarli yazma, kisaltma
- Anlatım kipini doğru kullanma

Hikâye Edici Metin: Öğrencilerin okuyup özetlemeleri için "Bayrağımı̨̨n Altında” adlı hikâye edici metin kullanılmıştır. Metin, Halide Edip Adıvar'ın hikâyeler ve mektuplardan oluşan İmir'den Bursa'ya adlı kitabından kısaltılarak yeniden düzenlenen hikâye edici bir metindir. 353 kelimeden oluşan hikâye edici bu metin MEB Talim ve Terbiye Kurulu'nun Türkçe 2008 yllinda ders kitabı olarak kabul ettiği kitaptan alınmıştır.

\subsection{Verilerin Toplanmas1}

Araştırmanın verileri, 2017 yılında ocak, şubat ve mart aylarında araştırmacılar tarafından toplanmıştır. Veri toplama aracının uygulanması iki oturum şeklinde gerçekleştirilmiştir: İlk oturumda "İlkokul Dördüncü Simf Öğgrencileri İçin Özetlemeye Yönelik Görüşme Formu” uygulanmıștır. Bu uygulama ortalama 25 dakika sürmüştür. İkinci oturumda öğrenciler "Bayrağımızın Altında" adlı metin öğrencilere dağıltılmış, bir veya iki kez okumaları için makul miktarda süre verilmiştir. Öğrenciler okumayı tamamladıktan sonra metinler toplanmış ve özetini yazmaları için öğrencilere çizgili boş çalışma kağıdı verilmiştir. Öğrenciler, ortalama 15-45 dakika içinde özeti yazarak tamamlamışlardır.

\subsection{Verilerin Çözümlenmesi}

Verilerin çözümlenmesinde öncelikle toplanan form ve özetlerin sayımı ve tasnifi yapılmıştır. Bu aşamada okunamayan özetler ve değerlendirme için yeterli olmayan formlar çözümlemeye dâhil edilmemiştir. Öğrencilerin yazdıkları özetler "Özetleme Stratejileri Puanlama 
Kuşdemir, Y., Düşünsel, C. M., \& Çelik, M. (2018). İlkokul öğrencilerinin özetleme becerilerinin incelenmesi. Journal of Human Sciences, 15(2), 893-910. doi:10.14687/ihs.v15i2.5208

Ölçeği” kullanılarak puanlanmıştır. Tüm veriler bilgisayar üzerinde istatistik paket program kullanılarak çözümlenmiştir.

Araştırma kapsamında ilkokul dördüncü sınıf öğrencilerinin özet yazma becerilerinin incelenmesi amaçlanmış ve bu genel amaç doğrultusunda öğrencilerin özet, başlık yazma, önemli bilgileri belirleme ve kısaltabilme becerilerine ait puanlarının cinsiyet, öğretmen cinsiyeti, sınıf değiştirme durumları ve okuma-yazma tercihleri değişkenlerine ait kategorilerde anlamlı farklılık gösterip göstermediği incelenmiştir. Ayrıca dördüncü sınıf öğrencilerinin özet yazma becerilerinin incelenmesi amacıyla, özet yazarken zorlanma durumları, özet yazmayı kimden öğrendikleri, özetlerinin kim tarafindan kontrol edildiği ve özet yazma sıklıklarına ait bazı istatistikler sunulmuştur.

\section{Bulgular}

\section{1.İlkokul Dördüncü Sınıf Öğrencilerinin Hikâye Edici Metinleri Özet Yazabilme Durumlarının İncelenmesi}

Araştırmaya katılan öğrencilerin özet yazabilme, yazılan özete başlık yazabilme, kaynak metindeki önemli bilgileri seçebilme ve özet metinlerde kısaltma yapabilme değişkenlerine ait betimsel istatistikler Tablo 2'de yer almaktadır.

Tablo 2. Özet yazabilme durumuna ilişkin betimsel istatistikler

\begin{tabular}{lcccccc}
\hline \multicolumn{1}{c}{ Değişken } & N & Min. & Max. & Ortalama & Çarpıklık & Basıklık \\
\hline $\begin{array}{l}\text { Özetleme Genel } \\
\text { Puanı }\end{array}$ & 247 & 3 & 85 & 32,95 &, 65 &,- 38 \\
\hline Özete Başlık Yazma & 247 & 0 & 10 & 2,88 &, 94 & $-1,10$ \\
\hline $\begin{array}{l}\text { Özette Önemli } \\
\text { Bilgiye Yer Verme }\end{array}$ & 247 & 5 & 30 & 10,24 & 1,35 & 1,36 \\
\hline $\begin{array}{l}\text { Kaynak Metni } \\
\text { Kisaltma }\end{array}$ & 247 & 0 & 10 & 2,31 & 1,18 &, 06 \\
\hline
\end{tabular}

Tablo 2’ye göre dördüncü sınıf öğrencilerinin özet yazabilme, başlık yazabilme, önemli bilgileri seçebilme ve özet metinlerde kısaltma yapabilme değişkenlerine ait ortalama puanları düşük seviyededir. Min ve max değerleri incelendiğinde de öğrencilerin bu değişkenlere ait puan ranjlarının geniş bir aralığa sahip olduğu söylenebilir. Çarpıklık ve basıklık değerleri incelendiğinde ise, özet puanı değişkenine ait çarpıklık ve basıklık değerlerinin -1 ve +1 aralığında yer almasından dolayı özet puanına ait dağılımın normal olduğu söylenebilir. Ancak, başlık yazabilme, önemli bilgileri seçebilme ve özet metinlerde kısaltma yapabilme değişkenlerine ait çarpıklık ve basıklık değerlerinin -1 ve +1 arasında yer almadığı bu nedenle bu değişkenlere ait puanların normal dağılıma sahip olmadığı görülmektedir.

Dördüncü sınıf öğrencilerinin özet yazabilme puanlarına ait çarpıklık ve basıklık değerleri, cinsiyet ve öğretmen cinsiyeti değisskenlerinin alt kategorilerinde -1 ile +1 arasında yer almasından dolayı özet yazabilme puanlarının bu değişkenlerin kategorilerinde normal dağılıma sahip olduğu, ancak sınıf değişimi ve okuma-yazma tercihi değişkenlerinin alt kategorilerinde -1 ile +1 arasında yer almamasından dolayı özet yazabilme puanlarının bu kategorilerde normal dağılıma sahip olmadığı tespit edilmiştir. Bu nedenle dördüncü sınıf öğrencilerinin özet yazabilme puanlarının, cinsiyet ve öğretmen cinsiyeti değişkenlerine göre farkllılı gösterip göstermediği incelenirken parametrik testler, sınıf değişimi ve okuma-yazma tercih değişkenlerine göre farklılık gösterip göstermediği incelenirken nonparametrik testlere yer verilmiştir. Değişkenlere ait kategori sayısının iki olması durumunda parametrik testlerden bağımsız örneklem t testi, nonparametrik testlerden Mann-Whitney U testi, kategori sayısının ikiden fazla olması durumunda parametrik testlerden Tek Yönlü ANOVA, nonparametrik testlerden Kruskal Wallis testleri kullanılmıştır. Elde edilen sonuçlar Tablo 3’te sunulmuştur. 
Kuşdemir, Y., Düşünsel, C. M., \& Çelik, M. (2018). İlkokul öğrencilerinin özetleme becerilerinin incelenmesi. Journal of Human Sciences, 15(2), 893-910. doi:10.14687/jhs.v15i2.5208

Tablo 3.Özet yazabilme genel puanı ve değişkenlerin karşılaştırılması

\begin{tabular}{|c|c|c|c|c|c|c|}
\hline T Testi & Grup & $\mathbf{N}$ & Ortalama & sd & $\mathrm{t}$ & $\mathrm{p}$ \\
\hline \multirow{2}{*}{ Öğrenci Cinsiyeti } & $\mathrm{K}_{12}$ & 132 & 35,48 & \multirow{2}{*}{245} & \multirow{2}{*}{2,29} & $\overline{0,0}$ \\
\hline & Erkek & 115 & 30,04 & & & 2 \\
\hline \multirow[b]{2}{*}{ Öğretmen Cinsiyeti } & Kadın & 116 & 30,30 & \multirow[b]{2}{*}{244} & \multirow[b]{2}{*}{2,11} & 0,0 \\
\hline & Erkek & 130 & 35,44 & & & 3 \\
\hline $\begin{array}{c}\text { Mann Whithney U } \\
\text { Testi }\end{array}$ & Grup & $\mathbf{N}$ & Sira Ortalama & Sira toplamı & $\mathbf{U}$ & $\mathrm{p}$ \\
\hline \multirow{2}{*}{ Öğretmen-Okul Değişimi } & Evet & 137 & 125,76 & 17228,50 & \multirow{2}{*}{$\begin{array}{c}6061,5 \\
0\end{array}$} & \multirow{2}{*}{$\begin{array}{c}0,1 \\
0\end{array}$} \\
\hline & Hayır & 101 & 111,01 & 11212,50 & & \\
\hline Kruskal Wallis Testi & Grup & $\mathrm{N}$ & Sira Ortalama & sd & $\begin{array}{c}\text { Ki- } \\
\text { Kare }\end{array}$ & $\mathrm{p}$ \\
\hline \multirow{4}{*}{ Okuma-Yazma Tercihi } & Kitap & 40 & 132,94 & \multirow{4}{*}{3} & \multirow{4}{*}{2,80} & \multirow{4}{*}{$\begin{array}{c}0,4 \\
2\end{array}$} \\
\hline & Yaz1 & 16 & 98,00 & & & \\
\hline & $\begin{array}{l}\text { Hem kitap } \\
\text { hem yaz1 }\end{array}$ & 173 & 123,97 & & & \\
\hline & Hiçbiri & 17 & 120,56 & & & \\
\hline
\end{tabular}

Tablo 3’teki T Testi sonuçları incelendiğinde, dördüncü sınıf öğrencilerinin özetleme genel puanları öğrencinin cinsiyet ve öğretmen cinsiyetine göre anlamlı farklılık göstermektedir $\left(\mathrm{t}_{\mathrm{C}}(245)=2,29, \mathrm{p}<0,05 ; \mathrm{t}_{\mathrm{ÖC}}(244)=2,11, \mathrm{p}<0,05\right)$. Bu farklillk öğrenci cinsiyetlerine göre ele alındığında kız öğrencilerin lehinedir. Öğretmen cinsiyeti bakımından ise öğretmeni erkek olan öğrencilerin lehinedir. Bu bulguya göre, öğrencilerin özet yazabilme puanları ile öğrenci cinsiyeti ve öğretmen cinsiyeti arasında anlamlı bir ilişkinin olduğu söylenebilir. Tablo 2'de yer alan Mann Whithney U Testi ve Kruskal Wallis Testi sonuçları incelendiğinde dördüncü sinıf öğrencilerinin özet yazabilme puanlarının sınıf değişme durumu ve okuma yazma tercihlerine göre anlamlı farklılık göstermediği tespit edilmiştir ( $\mathrm{p}>0,05)$. Başka bir ifadeyle, dördüncü sınıf öğrencilerinin özet yazabilme puanları sınıfını değişen ve değişmeyen öğrencilerde benzerlik gösterdiği ifade edilebilir. Öte yandan okuma-yazma tercihlerinin de öğrencilerin özet yazabilme puanları arasında bir farklılık oluşturmadığı söylenebilir.

Dördüncü sınıf öğrencilerinin başlık yazabilme puanlarına ait çarpıklık ve basıklık değerleri, cinsiyet, öğretmen cinsiyeti, sınıf değişimi ve okuma-yazma tercihi değişkenlerinin alt kategorilerinde -1 ile +1 arasında yer almamasından dolayı başlık yazabilme puanlarının bu değişkenlerin kategorilerinde normal dağılıma sahip olmadığı tespit edilmiştir. Bu nedenle dördüncü sınıf öğrencilerinin başlık yazabilme puanlarının, cinsiyet ve öğretmen cinsiyeti, sınıf değişimi ve okuma-yazma tercihi değişkenlerine göre farkllılı gösterip göstermediği incelenirken nonparametrik testlere yer verilmiştir. Değişkenlere ait kategori sayısının iki olması durumunda Mann-Whitney U testi ikiden fazla olması durumunda Kruskal Wallis testleri kullanılmıştır. Elde edilen sonuçlar Tablo 4'te yer almaktadır.

Tablo 4. Özete başlık yazabilme puanları

\begin{tabular}{|c|c|c|c|c|c|c|}
\hline $\begin{array}{c}\text { Mann Whithney U } \\
\text { Testi }\end{array}$ & Grup & $\mathbf{N}$ & Sira Ortalama & $\begin{array}{c}\text { Sira } \\
\text { toplamı }\end{array}$ & $\mathbf{U}$ & $\mathrm{p}$ \\
\hline \multirow{2}{*}{ Cinsiyet } & $\mathrm{K}_{12}$ & 132 & 119,33 & 15751,00 & \multirow[b]{2}{*}{6973,00} & \multirow{2}{*}{0,17} \\
\hline & Erkek & 115 & 129,37 & 14877,00 & & \\
\hline \multirow{2}{*}{ Öğretmen cinsiyeti } & Kadin & 116 & 122,94 & 14261,00 & \multirow{2}{*}{7475,00} & \multirow{2}{*}{0,88} \\
\hline & Erkek & 130 & 124,00 & 16120,00 & & \\
\hline \multirow{2}{*}{ Sınıf değişimi } & Evet & 137 & 121,60 & 16659,50 & \multirow{2}{*}{6630,50} & \multirow{2}{*}{0,49} \\
\hline & Hayır & 101 & 116,65 & 11781,50 & & \\
\hline
\end{tabular}


Kuşdemir, Y., Düşünsel, C. M., \& Çelik, M. (2018). İlkokul öğrencilerinin özetleme becerilerinin incelenmesi. Journal of Human Sciences, 15(2), 893-910. doi:10.14687/jhs.v15i2.5208

\begin{tabular}{|c|c|c|c|c|c|c|}
\hline Kruskal Wallis Testi & Grup & $\mathrm{N}$ & Sira Ortalama & sd & $\begin{array}{l}\text { Ki- } \\
\text { Kare }\end{array}$ & \\
\hline \multirow{4}{*}{ Okuma-yazma tercih } & Kitap & 40 & 111,50 & \multirow{4}{*}{3} & \multirow{4}{*}{2,32} & \multirow{4}{*}{0,51} \\
\hline & Yaz1 & 16 & 123,31 & & & \\
\hline & Hem kitap hem yaz1 & 173 & 126,53 & & & \\
\hline & Hiçbiri & 17 & 121,03 & & & \\
\hline
\end{tabular}

Tablo 4'te bulunan Mann Whithney U Testi ve Kruskal Wallis Testi sonuçları incelendiğinde dördüncü sınıf öğrencilerinin başlık yazabilme puanlarının cinsiyet, öğretmen cinsiyeti, sınıf değişme durumu ve okuma yazma tercihlerine göre anlamlı farklılık göstermediği tespit edilmiştir $(\mathrm{p}<0,05)$. Başka bir ifadeyle, dördüncü sınıf öğrencilerinin başlık yazabilme puanları bu değişkenlerin alt kategorilerinde benzerlik göstermektedir.

Dördüncü sınıf öğrencilerinin önemli bilgileri belirleme puanlarına ait çarpıklık ve basıklık değerleri, cinsiyet, öğretmen cinsiyeti, sınıf değişimi ve okuma-yazma tercihi değişkenlerinin alt kategorilerinde -1 ile +1 arasında yer almamasından dolayı başlık yazabilme puanlarının bu değişkenlerin kategorilerinde normal dağılıma sahip olmadığı tespit edilmiştir. Bu nedenle dördüncü sınıf öğrencilerinin önemli bilgileri belirleme puanlarının, cinsiyet ve öğretmen cinsiyeti, sınıf değişimi ve okuma-yazma tercihi değişkenlerine göre farkllık gösterip göstermediği incelenirken nonparametrik testlere yer verilmiştir. Değişkenlere ait kategori sayısının iki olmas1 durumunda Mann-Whitney U testi ikiden fazla olması durumunda Kruskal Wallis testleri kullanılmıştır. Elde edilen sonuçlar Tablo 5'te yer almaktadır.

Tablo 5. Kaynak metindeki önemli bilgileri belirleme puanları

\begin{tabular}{|c|c|c|c|c|c|c|}
\hline $\begin{array}{c}\text { Mann Whithney U } \\
\text { Testi }\end{array}$ & Grup & $\mathbf{N}$ & $\begin{array}{c}\text { Sira } \\
\text { Ortalama }\end{array}$ & $\begin{array}{c}\text { S1ra } \\
\text { toplami }\end{array}$ & $\mathbf{U}$ & $\mathrm{p}$ \\
\hline \multirow{2}{*}{ Cinsiyet } & $\mathrm{K}_{12}$ & 132 & 135,89 & 17937,00 & \multirow{2}{*}{6021,00} & \multirow{2}{*}{0,00} \\
\hline & Erkek & 115 & 110,36 & 12691,00 & & \\
\hline \multirow{2}{*}{ Öğretmen cinsiyeti } & Kadin & 116 & 116,09 & 13467,00 & \multirow{2}{*}{6681,00} & \multirow{2}{*}{0,08} \\
\hline & Erkek & 130 & 130,11 & 16914,00 & & \\
\hline \multirow{2}{*}{ Sınıf değişimi } & Evet & 137 & 125,11 & 17139,50 & \multirow{2}{*}{6150,50} & \multirow{2}{*}{0,09} \\
\hline & Hayır & 101 & 111,90 & 11301,50 & & \\
\hline Kruskal Wallis Testi & Grup & $\mathrm{N}$ & $\begin{array}{c}\text { Sira } \\
\text { Ortalama }\end{array}$ & sd & Ki-Kare & \\
\hline \multirow{4}{*}{ Okuma-yazma tercih } & Kitap & 40 & 136,81 & \multirow{4}{*}{3} & \multirow{4}{*}{10,25} & \multirow{4}{*}{0,01} \\
\hline & Yaz1 & 16 & 78,66 & & & \\
\hline & Hem kitap hem vaz1 & 173 & 124,75 & & & \\
\hline & Hiçbiri & 17 & 121,71 & & & \\
\hline
\end{tabular}

Tablo 5'teki Mann Whithney U Testi ve Kruskal Wallis Testi sonuçları, dördüncü sınıf öğrencilerinin kaynak metindeki önemli bilgileri belirleme puanları cinsiyetlerine ve okuma yazma tercihlerine göre anlamlı farklılık olduğunu göstermektedir $\left(U_{C}=6021,00, p<0,05 ; X^{2}(3)=10,25\right.$, $\mathrm{p}<0,05)$. Bu farklılık öğrenci cinsiyetlerine göre ele alındığında kız öğrencilerin lehinedir. Okuma yazma tercihleri açısından ise nonparametric post hoc testlerine göre bu farklilık kitap ve yazı kategorileri arasında kitabı seçenler lehine, hem kitap hem yazı ve yazı kategorileri arasında ise hem kitap hem yazıyı seçenler lehinedir. Yani, kitap okumayı tercih edenlerin yazı yazmayı tercih edenlere göre, hem kitap okumayı hem de yazı yazmayı tercih edenlerin sadece yazı yazmayı tercih edenlere göre önemli bilgileri belirleme puanları daha yüksektir. Bu bulgulara göre, öğrencilerin önemli bilgileri belirleme puanları ile öğrenci cinsiyeti ve okuma yazma tercihleri arasında anlamlı bir ilişkinin olduğu söylenebilir. Tablo 4'te yer alan Mann Whithney U Testi sonuçları incelendiğinde dördüncü sınıf öğrencilerinin önemli bilgileri belirleme puanlarının öğretmenlerinin cinsiyetleri ve sınıf değişme durumlarına göre anlamlı farkllılı göstermediği tespit edilmiştir ( $p>0,05)$. Başka bir ifadeyle, dördüncü sınıf öğrencilerinin önemli bilgileri belirleme 
Kuşdemir, Y., Düşünsel, C. M., \& Çelik, M. (2018). İlkokul öğrencilerinin özetleme becerilerinin incelenmesi. Journal of Human Sciences, 15(2), 893-910. doi:10.14687/jhs.v15i2.5208

puanları sınıfinı değiş̧en ve değişmeyen öğrencilerde benzerlik gösterdiği ifade edilebilir. Öte yandan öğretmenlerin cinsiyetlerinin de öğrencilerin önemli bilgileri belirleme puanları arasında bir farklılık oluşturmadığı söylenebilir.

Dördüncü sınıf öğrencilerinin kısaltma yapabilme puanlarına ait çarpıklık ve basıklık değerleri, cinsiyet, öğretmen cinsiyeti, sınıf değissimi ve okuma-yazma tercihi değişkenlerinin alt kategorilerinde -1 ile +1 arasında yer almamasından dolayı başlık yazabilme puanlarının bu değişkenlerin kategorilerinde normal dağılıma sahip olmadığı tespit edilmiştir. Bu nedenle dördüncü sınıf öğrencilerinin kısaltma yapabilme puanlarının, cinsiyet ve öğretmen cinsiyeti, sınıf değişimi ve okuma-yazma tercihi değişkenlerine göre farklılık gösterip göstermediği incelenirken nonparametrik testlere yer verilmiştir. Değişkenlere ait kategori sayısının iki olması durumunda Mann-Whitney U testi ikiden fazla olması durumunda Kruskal Wallis testleri kullanılmıştır. Elde edilen bulgular Tablo 6'da sunulmuştur.

Tablo 6.Kaynak metni kısaltma puanları

\begin{tabular}{|c|c|c|c|c|c|c|}
\hline $\begin{array}{c}\text { Mann } \\
\text { Whithney U } \\
\text { Testi } \\
\end{array}$ & Grup & $\mathbf{N}$ & $\begin{array}{c}\text { Sira } \\
\text { Ortalama }\end{array}$ & $\begin{array}{c}\text { Sira } \\
\text { toplamı }\end{array}$ & $\mathbf{U}$ & $\mathrm{p}$ \\
\hline \multirow{2}{*}{ Cinsiyet } & $\mathrm{K}_{1 \mathrm{Z}}$ & 132 & 135,89 & 17937,00 & \multirow{2}{*}{6021,00} & \multirow{2}{*}{0,00} \\
\hline & Erkek & 115 & 110,36 & 12691,00 & & \\
\hline \multirow{2}{*}{$\begin{array}{c}\text { Öğretmen } \\
\text { cinsiyeti }\end{array}$} & Kadın & 116 & 116,09 & 13467,00 & \multirow{2}{*}{6681,00} & \multirow{2}{*}{0,08} \\
\hline & Erkek & 130 & 130,11 & 16914,00 & & \\
\hline \multirow[b]{2}{*}{ Sınıf değişimi } & Evet & 137 & 125,11 & 17139,50 & \multirow[b]{2}{*}{6150,50} & \multirow[b]{2}{*}{0,09} \\
\hline & Hayır & 101 & 111,90 & 11301,50 & & \\
\hline $\begin{array}{c}\text { Kruskal Wallis } \\
\text { Testi }\end{array}$ & Grup & $\mathrm{N}$ & $\begin{array}{c}\text { Sira } \\
\text { Ortalama }\end{array}$ & sd & Ki-Kare & \\
\hline \multirow{4}{*}{$\begin{array}{l}\text { Okuma-yazma } \\
\text { tercih }\end{array}$} & Kitap & 40 & 136,81 & \multirow{4}{*}{3} & \multirow{4}{*}{10,25} & \multirow{4}{*}{0,01} \\
\hline & Yaz1 & 16 & 78,66 & & & \\
\hline & $\begin{array}{c}\text { Hem kitap hem } \\
\text { vaz1 }\end{array}$ & 173 & 124,75 & & & \\
\hline & Hiçbiri & 17 & 121,71 & & & \\
\hline
\end{tabular}

Tablo 6'daki Mann Whithney U Testi sonuçları incelendiğinde, dördüncü sinıf öğrencilerinin kaynak metinleri kısaltma puanları öğretmen cinsiyetine göre, erkek öğretmenlerin öğrencileri lehine olacak biçimde anlamlı farklılık göstermektedir $\left(\mathrm{U}_{\mathrm{ÖC}}=6021,00, \mathrm{p}<0,05\right) . \mathrm{Bu}$ bulguya göre, kısaltma yapabilme puanları ile öğretmen cinsiyeti arasında anlamlı bir ilişkinin olduğu belirtilebilir. Tablo 6'daki sonuçlar incelendiğinde dördüncü sınıf öğrencilerinin kısaltma yapabilme puanlarının cinsiyet, sınıf değişme durumu ve okuma yazma tercihlerine göre anlamlı farklılık göstermediği tespit edilmiştir ( $\mathrm{p}>0,05)$.

Araştırma kapsamında ilkokul dördüncü sınıf öğrencilerinin özet yazma becerilerinin incelenmesi amacıyla, özet yazmayı kimden öğrendikleri, özetlerinin kim tarafindan kontrol edildiği, özet yazarken zorlanma durumları ve özet yazma sıkl1kları frekans ve ortalamalar açısından değerlendirilmiştir. Öğrencilerin özet yazmayı kimden öğrendikleri ne dair bulgular Tablo 7'de sunulmuştur.

Tablo 7. Özet yazmanın kimden öğrenildiğine dair dağılım

\begin{tabular}{lccccccccccc}
\hline $\begin{array}{l}\text { Özetlemeyi } \\
\text { kimden öğrendin? }\end{array}$ & $\mathbf{N}$ & $\mathbf{\%}$ & \multicolumn{3}{c}{ Başlık } & \multicolumn{3}{c}{ Kisaltma } & & \multicolumn{2}{c}{ Özetleme Puanı } \\
\hline Anne-baba & 33 & 13,36 & Ort. & Min & Max & Ort. & Min & Max & Ort. & Min & Max \\
\hline Arkadaş & 3 & 1,21 & 3,33 & 0 & 10 & 2,88 & 0 & 10 & 33,82 & 4 & 85 \\
\hline Öğretmen & 183 & 74,09 & 3,33 & 0 & 10 & 1,67 & 0 & 5 & 30,33 & 22 & 37 \\
\hline Kendim & 18 & 7,29 & 2,63 & 0 & 10 & 2,27 & 0 & 10 & 32,83 & 3 & 79 \\
\hline Hiç kimse & 5 & 2,02 & 4,44 & 0 & 10 & 2,50 & 0 & 10 & 36,00 & 8 & 80 \\
\hline Diğer & 5 & 2,02 & 4,00 & 0 & 10 & 1,00 & 0 & 5 & 27,40 & 10 & 45 \\
\hline Toplam & 247 & 100 & 2,00 & 0 & 10 & 1,00 & 0 & 5 & 27,80 & 15 & 51 \\
\hline
\end{tabular}


Kuşdemir, Y., Düşünsel, C. M., \& Çelik, M. (2018). İlkokul öğrencilerinin özetleme becerilerinin incelenmesi. Journal of Human Sciences, 15(2), 893-910. doi:10.14687/jhs.v15i2.5208

Tablo 7'den dördüncü sinıf öğrencilerinin büyük bir çoğunluğu 183'ü (\%74,09) özet yazmayı öğretmenlerinden öğrendiği anlaşılmaktadır. Geri kalan öğrencilerden ise 33’ü $(13,36)$ anne-babalarından, 18'i $(\% 7,29)$ kendileri, 5’i $(\% 2,02)$ diğer kişilerden, 5’i $(\% 2,02)$ hiç kimseden ve 3’ü $(\% 1,21)$ arkadaşlarından öğrendiğini belirtmiştir. Tablo 7 incelendiğinde öğrencilerin başlık yazabilmeye yönelik genel ortalamasının 2,88 olduğu ve özet yazmayı öğrendikleri kişiler farketmeksizin minimum puanlarının 0 ve maximum puanlarının 10 olup, tüm gruplarda aynı olduğu tespit edilmiştir. Ayrıca özet yazma becerilerini öğrendikleri kişilere göre başlık yazabilme ortalamaları incelendiğinde, en yüksek ortalamaya özet yazmayı kendi başına öğrenen öğrencilerin sahip olduğu görülmektedir. Öte yandan, Tablo 7'de görüldüğü üzere; özet yazmayı hiç kimseden öğrenmeyen, anne-babalarından veya arkadaşlarından öğrenen öğrencilerin başlık yazabilme ortalamalarının genel ortalamadan yüksek olduğu, öğretmenlerinden veya diğer kişilerden öğrenen öğrencilerin ise başlık yazabilme puanlarının genel ortalamadan düşük olduğu tespit edilmiştir.

Tablo 7 incelendiğinde, dördüncü sınıf öğrencilerinin kısaltma yapabilme puanlarına ait genel ortalamanın 2,31 olduğu ve özet yazmayı öğrendikleri kişilere göre minimum puanlarının 0 olacak biçimde her grupta aynı olduğu ancak maximum puanların özet yazmayı öğrenilen kişi gruplarına göre 5 ile 10 arasında farklılaştığ görülmektedir. Kısaltma yapabilmeye ait puanlar bakımından en yüksek ortalamaya özet yazmayı anne-babasından öğrenen öğrencilerin sahip olduğu tespit edilmiştir. Ayrıca, özet yazmayı kendi başına öğrenen öğrencilerin kısaltma yapabilme puanlarına ait ortalamanın genel ortalamadan yüksek olduğu ancak özet yazmayı hiç kimseden öğrenmeyen, öğretmenlerinden, arkadaşlarından veya diğer kişilerden öğrenenlerin kısaltma yapabilme puanlarına ait ortalamalarının genel ortalamadan düşük olduğu tespit edilmiştir. Tablo 7'de bulunan özet yazabilme puanları ele alındığında, genel ortalamanın 32,95 olduğu ve özet yazmayı öğrendikleri kişilere göre minimum puanlarının 3 ile 22 arasında, maximum puanların ise 37 ile 85 arasında farklılaştığı görülmektedir. Özet yazabilmeye ait puanlar bakımından en yüksek ortalamaya özet yazmayı kendi başına öğrenen öğrencilerin sahip olduğu tespit edilmiştir. Araştırmaya katılan öğrencilerin özet yazma sıklıkları ile ilgili bulgular Tablo 8'de yer almaktadir.

Tablo 8. İlkokul dördüncü sınıf öğrencilerinin özet yazma sılklıkları

\begin{tabular}{|c|c|c|c|c|c|c|c|c|c|c|c|}
\hline \multirow{2}{*}{$\begin{array}{l}\text { Özet Yazma } \\
\text { S1klığ1 }\end{array}$} & \multirow[t]{2}{*}{$\mathbf{N}$} & \multirow[t]{2}{*}{$\%$} & \multicolumn{3}{|c|}{ Başlık } & \multicolumn{3}{|c|}{ Kisaltma } & \multicolumn{3}{|c|}{ Özet Puanı } \\
\hline & & & Ort. & Min & Max & Ort. & Min & Max & Ort. & Min & Max \\
\hline Her zaman & 61 & 24,7 & 3,61 & 0 & 10 & 2,30 & 0 & 10 & 32,57 & 7 & 79 \\
\hline Ara sıra & 88 & 35,6 & 2,51 & 0 & 10 & 2,33 & 0 & 10 & 33,20 & 3 & 76 \\
\hline $\begin{array}{l}\text { Öğretmen } \\
\text { istediğinde }\end{array}$ & 90 & 36,4 & 2,79 & 0 & 10 & 2,39 & 0 & 10 & 34,29 & 5 & 85 \\
\hline Hiç & 7 & 2,8 & 2,86 & 0 & 10 & 0,00 & 0 & 0 & 17,29 & 5 & 31 \\
\hline Diğer & 1 & 0,4 & 0,00 & 0 & 0 & 10,0 & 10 & 10 & 23,00 & 23 & 23 \\
\hline Toplam & 247 & 100 & 2,88 & 0 & 10 & 2,31 & 0 & 10 & 32,95 & 3 & 85 \\
\hline
\end{tabular}

Tablo 8'e göre ilkokul dördüncü sınıf öğrencilerinin çoğunluğu 90’1 $(\% 36,4)$ öğretmen istediği zaman özet yazdığını ifade etmiştir. Geri kalan öğrencilerden ise 88'i $(13,36)$ ara sıra, 61' $\mathrm{i}$ $(\% 24,7)$ her zaman, 1’i $(\% 0,4)$ diğer sıklıkta özet yazdığını, 7’si $(\% 2,80)$ hiç özet yazmadığını belirtmiştir. Tablo 8 incelendiğinde öğrencilerin başlık yazabilmeye yönelik genel ortalamasının 2,88 olduğu ve özet yazma sıklıkları farketmeksizin minimum puanlarının 0 olacak biçimde her grupta aynı olduğu ancak maximum puanların özet yazma sıklıklarına göre 0 ile 10 arasında farklılaştığı görülmektedir. Ayrıca özet yazma sıklıklarına göre başlık yazabilme ortalamaları incelendiğinde, en yüksek ortalamaya her zaman özet yazan öğrencilerin sahip olduğu görülmektedir. Öte yandan, Tablo 8'den anlaş1lacağı üzere; ara sıra, öğretmen istediği zaman ve diğer sıklıklarda özet yazan öğrenciler ile hiç özet yazmayan öğrencilerin başlık yazabilme ortalamalarının genel ortalamadan düşük olduğu tespit edilmiştir 
Kuşdemir, Y., Düşünsel, C. M., \& Çelik, M. (2018). İlkokul öğrencilerinin özetleme becerilerinin incelenmesi. Journal of Human Sciences, 15(2), 893-910. doi:10.14687/jhs.v15i2.5208

Tablo 8 incelendiğinde, dördüncü sınıf öğrencilerinin kısaltma yapabilme puanlarına ait genel ortalamanın 2,31 olduğu ve özet yazma sıklıklarına göre minimum puanlarının 0 ile 10 arasında, benzer biçimde maximum puanlarının da 0 ile 10 arasında farklılaşttğı görülmektedir. Kısaltma yapabilmeye ait puanlar bakımından en yüksek ortalamaya diğer sıklıklarda özet yazan öğrencilerin sahip olduğu tespit edilmiştir. Ayrıca, ara sıra veya öğretmen istediği zaman özet yazan öğrencilerin kısaltma yapabilme puanlarına ait ortalamanın genel ortalamadan yüksek olduğu ancak her zaman özet yazan veya hiç özet yazmayan öğrencilerin kısaltma yapabilme puanlarına ait ortalamalarının genel ortalamadan düşük olduğu sonucuna ulaşılmıştır. Tablo 8'de bulunan özet yazabilme puanları ele alındığında, genel ortalamanın 32,95 olduğu ve özet yazma sıklıklarına göre minimum puanlarının 3 ile 23 arasinda, maximum puanların ise 23 ile 85 arasinda farklılaştığı görülmektedir. Özet yazabilmeye ait puanlar bakımından en yüksek ortalamaya öğretmen istediği zamanlarda özet yazan öğrencilerin sahip olduğu tespit edilmiştir. Ayrıca, ara sıra özet yazan ögrrencilerin özet yazabilme puanlarına ait ortalamanın genel ortalamadan yüksek olduğu, ancak her zaman veya diğer sıklıkta özet yazan ve hiç özet yazmayan öğrencilerin özet yazabilme puanlarına ait ortalamalarının genel ortalamadan düşük olduğu sonucuna ulaşılmıştır. Tablo 9'da öğrencilerin yazdıkları özet metinlerin kim tarafından kontrol edildiği ile ilgili analiz sonuçları yer almaktadır.

Tablo 9. Yazılan özetin kim tarafından kontrol edildiğine dair dağılım

\begin{tabular}{|c|c|c|c|c|c|c|c|c|c|c|c|}
\hline \multirow{2}{*}{$\begin{array}{l}\text { Özetin Kontrol } \\
\text { Edilmesi }\end{array}$} & \multirow[b]{2}{*}{$\mathbf{N}$} & \multirow[b]{2}{*}{$\%$} & \multicolumn{3}{|c|}{ Başlik } & \multicolumn{3}{|c|}{ Kisaltma } & \multicolumn{3}{|c|}{ Özet puanı } \\
\hline & & & Ort. & $\begin{array}{l}M \\
\text { in }\end{array}$ & Max & Ort. & Min & Max & Ort. & Min & Max \\
\hline Hiç kimse & 6 & 2,43 & 5,00 & 0 & 10 & 2,50 & 0 & 10 & 38,00 & 14 & 85 \\
\hline Arkadaş & 5 & 2,02 & 2,00 & 0 & 10 & 0,00 & 0 & 0 & 25,40 & 10 & 46 \\
\hline Öğretmen & 113 & 45,75 & 2,74 & 0 & 10 & 2,65 & 0 & 10 & 33,83 & 3 & 80 \\
\hline Anne-baba & 83 & 33,60 & 3,39 & 0 & 10 & 2,11 & 0 & 10 & 31,80 & 4 & 75 \\
\hline Kendim & 38 & 15,38 & 1,87 & 0 & 10 & 1,97 & 0 & 10 & 32,68 & 8 & 76 \\
\hline Diğer & 2 & 0,81 & 5,00 & 0 & 10 & 2,50 & 0 & 5 & 40,00 & 38 & 42 \\
\hline Toplam & 247 & 100 & 2,88 & 0 & 10 & 2,31 & 0 & 10 & 32,95 & 3 & 85 \\
\hline
\end{tabular}

Tablo 9'a göre, dördüncü sınıf öğrencilerinin çoğunluğu 113’ü $(\% 45,75)$ yazdıkları özet metinleri öğretmenlerinin kontrol ettiğini ifade etmiştir. Geri kalan öğrencilerden ise 83’ü $(\% 33,60)$ anne-babalarının, 38'i $(\% 15,88)$ kendilerinin, 5'i $(\% 2,02)$ arkadaşlarının, 2'si $(\% 0,81)$ diğer kişilerin kontrol ettiğini, $6(\% 2,43)$ öğrenci ise hiç kimsenin kontrol etmediğini ifade etmiştir. Tablo 9 incelendiğinde öğrencilerin basslık yazabilmeye yönelik genel ortalamasının 2,88 olduğu ve özetlerin kim tarafindan kontrol edildiği farketmeksizin minimum puanlarının 0 ve maximum puanlarının 10 olacak biçimde her grupta aynı olduğu görülmektedir. Ayrıca özetlerin kimin tarafindan kontrol edildiğine göre başlık yazabilme ortalamaları incelendiğinde, en yüksek ortalamaya hiç kimse tarafindan özetleri kontrol edilmeyen ve diğer kişiler tarafindan özetleri kontrol edilen öğrencilerin sahip olduğu görülmektedir. Yazdıkları özetler anne-babaları tarafindan kontrol edilen öğrencilerin başlık yazabilme ortalamalarının genel ortalamadan yüksek olduğu, öğretmenleri, arkadaşları veya kendileri tarafindan özetleri kontrol edilen öğrencilerin ise başlık yazabilme puanlarının genel ortalamadan düşük olduğu tespit edilmiştir. Kaynak metindeki önemli bilgi yazabilme puanları incelendiğinde, genel ortalamanın 10,24 olduğu ve özetlerinin kim tarafından kontrol edildiğine göre minimum puanlarının 5 olacak biçimde her grupta aynı olduğu ancak maximum puanların özeti kontrol eden kişi gruplarına göre 15 ile 30 arasında farklılaştığ anlaşılmaktadır.

Ayrıca, özetleri öğretmenleri veya kendileri tarafindan kontrol edilen öğrencilerin önemli bilgi yazabilme puanlarına ait ortalamanın genel ortalamadan yüksek olduğu ancak arkadaşları, anne-babaları veya diğer kişiler tarafından özetleri kontrol edilen öğrencilerin önemli bilgi yazabilme puanlarına ait ortalamalarının genel ortalamadan düşük olduğu sonucuna ulaşılmıştır. Tablo 9 incelendiğinde, dördüncü sınıf öğrencilerinin kısaltma yapabilme puanlarına ait genel 
Kuşdemir, Y., Düşünsel, C. M., \& Çelik, M. (2018). İlkokul öğrencilerinin özetleme becerilerinin incelenmesi. Journal of Human Sciences, 15(2), 893-910. doi:10.14687/jhs.v15i2.5208

ortalamanın 2,31 olduğu özetlerinin kim tarafindan kontrol edildiğine göre minimum puanlarının 0 olacak biçimde her grupta aynı olduğu ancak maximum puanların özeti kontrol eden kişi gruplarına göre 0 ile 10 arasında farklılaştığı görülmektedir. Kısaltma yapabilmeye ait puanlar bakımından en yüksek ortalamaya özetleri öğretmenleri tarafindan kontrol edilen öğrencilerin sahip olduğu tespit edilmiştir. Ayrıca, diğer kişiler tarafindan özeti kontrol edilen veya hiç kimse tarafından özeti kontrol edilmeyen öğrencilerin kısaltma yapabilme puanlarına ait ortalamanın genel ortalamadan yüksek olduğu arkadaşları, anne-babaları veya kendileri tarafindan özetleri kontrol edilen öğrencilerin kısaltma yapabilme puanlarına ait ortalamalarının genel ortalamadan düşük olduğu sonucuna ulaşılmıştır. Tablo 9'de bulunan özet yazabilme puanları ele alındığında, genel ortalamanın 32,95 olduğu ve özetlerin kim tarafindan kontrol edildiğine göre minimum puanlarının 3 ile 38 arasında, maximum puanların ise 42 ile 85 arasında farklılaştığı görülmektedir. Özet yazabilmeye ait puanlar bakımından en yüksek ortalamaya özetleri diğer kişiler tarafindan kontrol edilen öğrencilerin sahip olduğu tespit edilmiştir. Ayrıca, özetleri öğretmenleri tarafından kontrol edilen veya hiç kimse tarafindan kontrol edilmeyen öğrencilerin özet yazabilme puanlarına ait ortalamanın genel ortalamadan yüksek olduğu, ancak özetleri arkadaşları, anne-babaları veya kendileri tarafindan kontrol edilen öğrencilerin özet yazabilme puanlarına ait ortalamalarının genel ortalamadan düşük olduğu sonucuna ulaşılmıştır.

Tablo 10. Özet yazma sürecinde zorlanma durumunun incelenmesi

\begin{tabular}{|c|c|c|c|c|c|c|c|c|c|c|c|}
\hline \multirow{2}{*}{$\begin{array}{c}\text { Özet Yazmada } \\
\text { Zorlanma }\end{array}$} & \multirow{2}{*}{$\mathbf{N}$} & \multirow{2}{*}{$\%$} & \multicolumn{3}{|c|}{ Başlık } & \multicolumn{3}{|c|}{ Kisaltma } & \multicolumn{3}{|c|}{ Özet puanı } \\
\hline & & & Ort. & Min & Max & Ort. & Min & Max & Ort. & Min & Max \\
\hline Evet & 234 & 94,70 & 10,30 & 5 & 30 & 2,26 & 0 & 10 & 32,74 & 3 & 80 \\
\hline Hayır & 13 & 5,30 & 9,58 & 5 & 30 & 3,33 & 0 & 10 & 38,00 & 10 & 85 \\
\hline Toplam & 247 & 100 & 10,24 & 5 & 30 & 2,31 & 0 & 10 & 32,95 & 3 & 85 \\
\hline
\end{tabular}

Tablo 10'da belirtildiği gibi, dördüncü sınıf öğrencilerinin büyük bir çoğunluğu 234’ü $(\% 94,74)$ özet yazarken zorlandığını, 13’ü $(\% 5,30)$ ise zorlanmadığını ifade etmiştir. Tablo 9 incelendiğinde öğrencilerin başlık yazabilmeye yönelik genel ortalamasının 2,88 olduğu ve özet yazarken zorlanma durumları farketmeksizin minimum puanlarının 0 ve maximum puanlarının 10 olup, tüm gruplarda aynı olduğu tespit edilmiştir. Ayrıca özet yazarken zorlanma durumlarına göre başlık yazabilme ortalamaları incelendiğinde, özet yazarken zorlanmayan öğrencilerin başlık yazabilme puanlarına ait ortalamaların özet yazarken zorlanan öğrencilere göre daha yüksek olduğu sonucuna ulaşılmıştır. Önemli bilgileri yazabilme puanları ele alındığında, genel ortalamanın 10,24 olduğu ve özet yazarken zorlanma durumları farketmeksizin minimum puanlarının 0 ve maximum puanlarının 10 olup, tüm gruplarda aynı olduğu tespit edilmiştir. Ayrıca özet yazarken zorlanma durumlarına göre başlık yazabilme ortalamaları incelendiğinde, özet yazarken zorlanan öğrencilerin başlık yazabilme puanlarına ait ortalamaların özet yazarken zorlanmayan öğrencilere göre daha yüksek olduğu sonucuna ulaşılmıştır. Tablo 10 incelendiğinde, dördüncü sınıf öğrencilerinin kısaltma yapabilme puanlarına ait genel ortalamanın 2,31 olduğu ve özet yazarken zorlanma durumları farketmeksizin minimum puanlarının 0 ve maximum puanlarının 10 olup, tüm gruplarda aynı olduğu tespit edilmisstir. Ayrıca özet yazarken zorlanma durumlarına göre kısaltma yapabilme ortalamaları incelendiğinde, özet yazarken zorlanmayan öğrencilerin kısaltma yapabilme puanlarına ait ortalamaların özet yazarken zorlanan öğrencilere göre daha yüksek olduğu sonucuna ulaşılmıştır. Tablo 10 'da bulunan özet yazabilme puanları ele alındığında, genel ortalamanın 32,95 olduğu ve özet yazarken zorlanma durumlarına göre minimum puanlarının 3 ile 10 arasında, maximum puanların ise 80 ile 85 arasında farklılaştığ görülmektedir. Ayrıca, özet yazarken zorlanma durumlarına göre özet puan ortalamaları incelendiğinde, özet yazarken zorlanmayan öğrencilerin özet puanlarına ait ortalamaların özet yazarken zorlanan öğrencilere göre daha yüksek olduğu sonucuna ulaşılmıştır. 
Kuşdemir, Y., Düşünsel, C. M., \& Çelik, M. (2018). İlkokul öğrencilerinin özetleme becerilerinin incelenmesi. Journal of Human Sciences, 15(2), 893-910. doi:10.14687/jhs.v15i2.5208

\section{Sonuç ve Tartışma}

Araştırmaya katılan ilkokul dördüncü sınıf öğrencilerinin hikâye edici metinleri özetleme becerileri çeşitli değişkenlere göre analiz edilmiştir. Yapılan tasnif, inceleme ve değerlendirmelerin ardından elde edilen sonuçlar bu bölümde açıklanmıştır.

Araştırmaya 247 ilkokul öğrencisi katılmıştır. Bu öğrencilerin 173’ü hem okumayı hem de yazı yazmayı sevdiğini; 40'1 sadece kitap okumayı, 16's1 ise sadece yazı yazmayı daha tercih ettiğini belirtmiştir. Ayrıca katılımcı öğrencilerden 116'sının sınıf öğretmeni kadın; 130'unun sınıf öğretmeni ise erkektir. Bu araştırmada katılımcı öğrencilerin yalnızca hikaye edici metinleri özetleme becerileri incelenmiştir. Öğrencilerin hikâye edici metinlerin özetini yazabilme, özete başlık yazabilme, önemli bilgileri seçebilme ve özet metinlerde kısaltma yapabilme değişkenlerine ait ortalama puanları düşük seviyededir. Bu sonuçlar Akkaya ve Kırmızı (2008) tarafindan yapılan araştırmanın sonuçları ile benzerlik göstermektedir. Araştırmacılar ilköğretim dördüncü ve beşinci sınıf öğrencilerinin kendi kelime ve cümlelerini kullanarak özet yazmada başarılı olmadıklarını belirlemişlerdir. Özetleme becerisi ile ilgili yapılan araştırmaların pek çoğunda metin türlerini esas alan incelemeler mevcuttur. Bulut (2013) beşinci sınıf öğrencileriyle yaptığı araştırmada öğrencilerin yazdığ1 özetlerin özetleme ölçütlerini karşlama düzeyi bakımından metin türüne göre değiştiği; öğrencilerin hikâye edici türdeki metinleri özetlemede bilgi verici metinlere göre daha başarıll olduğu sonucuna ulaşmıştır. Araştırmanın sonuçlarından biri de ilkokul dördüncü sınıf öğrencilerinin özet yazabilme puanlarının cinsiyete göre anlamlı farklılık göstermiş olmasıdır. Kız öğrencilerin erkeklere göre daha başarılı olduğu anlaşılmaktadır. Çalışma grubunu oluşturan öğrencilerin sınıf öğretmenlerinin cinsiyetini belirtmeleri istenmiştir. Öğretmen cinsiyeti değişkeni dikkate alındığında, sınıf öğretmeni erkek olan öğrencilerin özet yazmada daha başarılı olduğu anlaşılmaktadır. Ayrıca, ögrencilerin özet yazabilme puanları ile öğrenci cinsiyeti ve öğretmen cinsiyeti arasında anlamlı bir ilişki bulunmuştur. Özçakmak’ın (2015) öğretmen adaylarıyla yaptı̆̆ı araştırmada cinsiyet değişkeninin öğrencilerin özetleme becerileri üzerinde anlaml bir fark oluşturup oluşturmadığına yönelik yapılan analizlerde, bilgilendirici ve öyküleyici metin özetleme açısından kızlar lehine anlamlı bir farklılık olduğu tespit edilmiştir.

Özetleme, edinilen bilgilerin sınıflandırılmasını sağma işlemidir. Aynı zamanda mümkün olduğunca az kelimeyle metnin ana ifadesinin ortaya konulma sürecidir. Özetleme çalısmalarıyla beyin, edinilmiş bilgileri daha etkili bir biçimde sınıflandırma ve bilgiye ulaşma kolaylığı sağlamaktadır (Erdem, 2012: 37).Araştırmada ulaşılan sonuçlardan bir diğeri, araştırmaya katılan öğrencilerin özet yazarken önemli bilgileri belirleme puanları cinsiyete ve okuma-yazma tercihlerine göre anlamlı farklılık göstermiş olmasıdır. Kızlar kaynak metindeki önemli bilgileri özet metne aktarabilme hususunda erkeklere göre daha başarılıdır. Araştırmaya katılan öğrencilerin, özet yazabilme puanları öğretmen değiştiren ve değiştirmeyen öğrencilerde benzerlik gösterdiği ifade edilebilir. Öte yandan okuma-yazma tercihlerinin de öğrencilerin özet yazabilme puanları arasında bir farklılık oluşturmadığı belirtilebilir. Kitap okumayı tercih edenlerin yazı yazmayı tercih edenlere göre, hem kitap okumayı hem de yazı yazmayı tercih edenlerin sadece yazı yazmay1 tercih edenlere göre önemli bilgileri belirleme puanları daha yüksektir. Öğrencilerin önemli bilgileri belirleme puanları ile öğrenci cinsiyeti ve okuma yazma tercihleri arasında anlamlı bir ilişki vardır.

Bir metnin iyi yazılmıs özeti, onu yazan öğrencinin okuduğunu anladığını gösterir. İyi özetler yazabilen/üreten öğrenciler, metindeki tüm düzenlemeyi-yapıyı ve temasını öğrenirler. Metin içinde açıkça belirtilmeyen ancak metni anlamak için gerekli olan fikirler ve ilişkiler hakkında çıkarsama yapabilmek için "satırlar arasında okuma" yapmayı mümkün kılan özetleme, öğrenmenin devam etmesini kolaylaştırır (Westby, Culatta, Lawrence, Hall-Kenyon, 2010: 286). Araştırmaya katılan öğrencilerin \% 74 ’ü özet yazmay1 öğretmenlerinden öğrendiklerini ifade etmiştir. Öğrencilerin yazdıkları özet metne başlık yazabilme puanları incelendiğinde, özet yazmay1 anne-babalarından veya arkadaşlarından öğrenen öğrencilerin başlık yazabilme ortalamalarının genel ortalamadan yüksek olduğu belirlenmiştir. Özet yazmayı okulda öğretmenlerinden veya diğer kişilerden öğrenen öğrencilerin ise başlık yazabilme puanlarının 
Kuşdemir, Y., Düşünsel, C. M., \& Çelik, M. (2018). İlkokul öğrencilerinin özetleme becerilerinin incelenmesi. Journal of Human Sciences, 15(2), 893-910. doi:10.14687/jhs.v15i2.5208

genel ortalamadan düşük olduğu tespit edilmiştir. Önemli bilgi yazabilmeye ait puanlar bakımından en yüksek ortalamaya özet yazmayı anne-babasından öğrenen öğrencilerin sahip olduğu tespit edilmiştir. Kaynak metnin kısaltılmasında özet yazmayı anne-babasından öğrenen öğrencilerin en yüksek puanlara sahip oldukları anlaşılmıştır. "Başlık, ana düşünceyle özellikle de konuyla ilgilidir. Metnin tamamını kapsar. Bir bakıma başlık, okuyucunun okuyacağı metinle ilgili bilgilerin tümünü kapsayıcı bir ön söyleme biçimidir. Bu kısa sözcük ya da sözcük grubu okuyucuda birçok işlevler yerine getirir" (Günay, 2007; Akt: Coşkun, 2011: 30). Belet (2005) tarafindan yapılan öğrenme stratejilerinin okuduğunu anlama ve yazma becerileri ile Türkçe dersine ilișkin tutumlara etkisini belirlemeye yönelik araştırmada, özetleme stratejisine ilișkin "okunan materyaldeki başlı̆̆ bulma" ve "materyalde anlatılmak istenen ana fikri bulma" davranışlarının gözlem sistematiği içinde; göreceli olarak daha az kazanıldığı sonucuna ulaşılmıştır. Ç1krıkçı (2004) belirli bir metin yapısının özet metin yapısına dönüştürülmesi sürecinde metindeki hangi birimlerin ve ne tür stratejilerin kullanıldığını araştırmıştır. Beşinci sınıf öğrencilerinin özetleme ediminde, en çok doğrudan alınt1 ve alıntı stratejilerini kullandığı, öğrencilerin doğrudan alıntı stratejisini çok kullanmaları nedeniyle, metnin içerik bütünlügünde sapmaların az olduğu görülmektedir.

İlkokul dördüncü sınıf öğrencilerinin \%36's1 öğretmeni istediği zaman; \% 36’s1 ara sıra; \% 25’i her zaman özet yazmaktadır. Özet yazabilmeye ilişkin genel puanlar incelendiğinde de öğretmen istediği zaman özet yazanların en yüksek puanı aldığı sonucuna ulaşılmıştır. Kutlu, Yıldırım, Bilican ve Kumandaş'in (2011) yaptıkları araştırmada, ilköğretim beşinci sınıf öğrencilerinin okuduğunu anlama becerileri üzerinde öğrenciye ait kitap sayıs1, öğretmenin okunan metinlerle ilgili özet yazdırması ve öğretmenin okumayla ilgili ev ödevi vermesi değişkenlerinin anlamlı düzeyde etkili olduğu sonucuna ulaşılmıştır.

Öğrencilerin yazdıkları özetlerin kurallara uygunluğunun denetlenmesi ve geri dönütler verilmesi de bu becerinin geliştirilmesi bakımında mühim bir etkendir. Araştırma sonuçlarına göre ilkokul dördüncü sınıftaki öğrencilerin özetleri \%46's1 sınıf öğretmeni, \%34’ü anne-babalar tarafından kontrol edilmektedir. Genel özet yazma puanları mukayese edildiğinde özetleri öğretmenleri tarafından kontrol edilen veya hiç kimse tarafından kontrol edilmeyen öğrencilerin yüksek olduğu sonucuna ulaşılmıştır. Özetleme, okuduğunu anlamanın bir göstergesi ve anlama düzeyini geliştiren temel stratejilerden biridir Özetleme, öğrencileri metni okurken etkin olarak metinle meşgul olmaya zorlamak için gerçekten iyi bir yoldur (Rose, 2001: 31). Öğrencilerin hikâye edici metinleri anlama düzeyleri yükseldikçe hikâye edici metin özetlerinde kullandıkları özetleme başarısı da artmaktadır (Bulut, 2013: 129). Ekiz, Erdoğan ve Uzuner (2012) tarafindan yapılan araştırmaya göre, okuduğunu anlama becerisi yetersiz olan öğrencilerin bu becerilerinin geliştirilmesinde TİÖD (Tahmin-İnceleme-Özetleme-Örgütleme-Değerlendirme) stratejisi etkilidir ve öğrencilerin okuduğunu anlama becerisini geliştirmiştir. Özet yazma ile ilgili sorunların sebebi incelendiğinde öğrencilerin metni okumak için ayrılan zamanın yetersiz olmasıdır. Gerçekten anlaşılmayan bir metnin doğru şekilde özetlenmesi güçleşmektedir. Özetleme becerilerinin geliştirilmesinin akademik başarı ve genel okuryazarlık becerilerini de etkileyeceği düşünülmektedir. Bu çerçevede araştırmanın sonuçlarına uygun olarak bazı öneriler geliştirilmiştir:

Öğretmenler not alma ve özetleme stratejilerinin öğretimi konusunda kendilerini geliştirmeli, not alma ve özetlemenin nasıl yapılacağı hususunda öğrencilere doğru rehberlik yapmalıdırlar. Özet yazma sürecinde ögrenci tek başına bırakılmamalı, okunan metni özetleme sebepleri öğrencilere açıklanmalı, özetleme aşamaları öğrencilere gösterilmelidir.

Konu ile ilgili yapılabilecek araştırmalarda sınıf öğretmenlerinin özet yazmayı öğretme süreci ele alınabilir. Özet yazamayan öğrencilerin özetleme ve anlama becerilerini geliştirmeye yönelik eylem araştırmaları tasarlanabilir. Özet yazmanın Türkçe dersi kapsamında öğrenilmesine karşın diğer tüm derslerde de kullanılabildiği gerçeğinden hareketle ilkokul öğrencilerinin özetleme becerilerinin fen ve sosyal bilgiler derslerindeki başarılarına olan katkısı incelenebilir. $\mathrm{Bu}$ araştırmada sadece hikâye edici metinlere yönelik özetleme becerileri incelenmiştir. Bilgilendirici metinlerin özetlenmesi sürecini inceleyen farklı çalışmalar yapılabilir. Ayrıca hem ilkokul hem de 
Kuşdemir, Y., Düşünsel, C. M., \& Çelik, M. (2018). İlkokul öğrencilerinin özetleme becerilerinin incelenmesi. Journal of Human Sciences, 15(2), 893-910. doi:10.14687/jhs.v15i2.5208

ortaokul öğrencilerini kapsayan boylamsal araştırmalarda okuma ve yazma becerilerinin birlikte kullanıldığı Özetlemeyi etkileyen unsurlar incelenebilir. Okullarda kullanılan Türkçe kitaplarındaki metinlerin okuma, anlama ve özetleme becerilerini geliştirmeye uygunluğunu irdeleyen özgün araştırmalar da tasarlanabilir.

\section{Kaynaklar}

Akkaya, N., Kırmızı, F.S.(2008).İlkögretim birinci kademede özetleme stratejisinin kullanmmmn değerlendirilmesi. VII. Ulusal Sınıf Öğretmenliği Eğitimi Sempozyumu, 2-4 Mayıs. Çanakkale Onsekiz Mart Üniversitesi, Çanakkale.

Aktaş, N.(2015).Okuma öncesi strateji ögretiminin 4. sme ögrencilerinin ekrandan okuduğunu anlama düzeyine etkisi. Yayımlanmamış yüksek lisans tezi.Gazi Üniversitesi, Ankara.

Akyol, H. (2012). Programa uygun Türkşe ögretim yöntemleri. Ankara: Pegem Akademi Yayınları

Ayçin, A.(2009).ISOTEG tekniğinin beşinci sime ögrencilerinin okuduğunu anlama bassarısı ve okumaya yönelik tutumlar üzerine etkisi YIBO örneği. Yayımlanmamış yüksek lisans tezi, Çukurova Üniversitesi, Adana.

Batmaz, O.(2017). Ilkokul 4. sme ögrencilerinin Türkşe dersinde okuduğunu anlama stratejilerini kullanma düzeyleri ile okuduğunu anlama başar düzeyleri arasındaki ilişki. Yayımlanmamış yüksek lisans tezi. Bayburt Üniversitesi Sosyal Bilimler Enstitüsü, Bayburt.

Belet, D.(2005).Öğrenme stratejilerinin okuduğunu anlama ve yažma becerileri ile Türkse dersine iliskin tutumlara etkisi. Yayınlanmamış doktora tezi, Anadolu Üniversitesi, Eskişehir.

Beydoğan, H. Ö.(2010).Okuma ve anlamayı etkileyen stratejiler. Milli Eğitim, 39(185), 8-21.

Bozpolat, E. (2012). Türkse dersinde birlesstirilmiş işbirlikli okuma ve kompozisyon tekniği ile kullamilan bikaye haritast yönteminin ögrencilerde okuduğunu anlama becerisini geliștirmeye etkisi. Yayımlanmamış doktora tezi, Fırat Üniversitesi, Elazığ.

Bulut, P.(2013).Illkögrretim beşinci smnf ögrencileri ve ögretmenlerinin özetleme stratejilerinin değerlendirilmesi: Türkçe dersi örneği. Yayımlanmamış doktora tezi, Gazi Üniversitesi, Ankara.

Bulut, P.(2006).Kavram gelistirme yönteminin ilköğretim 5. sinf öğrencilerinin kelime hazinelerini gelistirmeye etkisi. Yayınlanmamış Yüksek Lisans Tezi, Gazi Üniversitesi, Ankara.

Cohen, L., Manion, L. \& Morrison, K.(2007).Research methods in education, 6.bask1 New York: Routledge, Taylor \& Francis

Coşkun, S.(2011).Bilissel farkindahk stratejilerine dayal okuma eğitimi etkinliklerinin okuduğunu anlama becerilerini geliștirmeye etkisi. Yayınlanmamış yüksek lisans tezi, Abant İzzet Baysal Üniversitesi, Bolu.

Çakıroğlu, A. (2007). Üstbilissel stratëi ögretimi ile okuduğunu anlama basar düreyi düşük olan ögrencilerin okuduğunu anlama erişi artirmmina etkisi. Yayımlanmamış doktora tezi. Gazi Üniversitesi, Ankara.

Ç1krrkçı, S.,S. (2004). İlköğretim ögrencilerinde özetleme becerisinin gelişimi. Yayınlanmamış Doktora Tezi. Ankara Üniversitesi, Ankara.

Duke, N. K., \& Pearson, P. D.(2008). Effective practices for developing reading comprehension. The Journal of Education, 189(1/2), 107-122.

Ekiz, D., Erdoğan, T.\& Uzuner, F.G. (2012). Aksiyon araştırması aracıllğıyla okuduğunu anlama becerisinin geliştirilmesi. The Journal of Academy Social Science Studies, 5 (7), 303-328.

Epçaçan, C., \& Erzen, M.(2010).Okuduğunu anlama becerileri ölçeği geçerlik ve güvenirlik çalışması. Milli Ë̈itim, 39(185), 22-32.

Erdem, C.(2012).Türk dili ve edebiyatı öğretmen adaylarının özetleme stratejilerini kullanım tercihleri ve metin dil bilimsel bir özetleme çalı̧̧̧ası. Dil ve Edebiyat Eğitimi Dergisi, 1(3), 36-52.

Ertem, İ. S. (2014). Okuma yazma eğitimi ve teknoloji. İ. S. Ertem (Ed.), Okuma yažma eğitimi ve teknoloji içinde (s. 51-60). Ankara: Nobel.

Fox, E.,\& Alexander, A.(2009). Text Comprehension. S.E. Israel ve G.G. Duffy (Edt.) Handbook Of Research On Reading Comprehension (1. Baskı) içinde (s.227-239) New York: Routledge

Göçer, A.(2014). Yažma eğitimi yažma uğraşı. Ankara: Pegem Akademi Yayınları

Görgen, İ.(1999).Özetleme becerisinin öğrencilere öğretimi. Yaşadıkşa Eğitim Dergisi, 62, 22-28.

Güneyli, A. (2007). Etkin ögrenme yaklaşsmmm anadili eğ̈itiminde okuma ve yażma becerilerini gelistirmeye etkisi. Yayımlanmamış doktora tezi, Ankara Üniversitesi, Ankara.

Gürbüz, M.(2014).Illkokul dördüncü simf ögrencilerinde SQ4R tekniğinin okuduğunu anlamaya etkisi. Uşak Üniversitesi, Uşak. 
Kuşdemir, Y., Düşünsel, C. M., \& Çelik, M. (2018). İlkokul öğrencilerinin özetleme becerilerinin incelenmesi. Journal of Human Sciences, 15(2), 893-910. doi:10.14687/jhs.v15i2.5208

Kanmaz, A. (2012).Okuğunu anlama stratejisi kullanımını, okuduğunu anlama becerisi, bilissel farkındahk, okumaya yönelik tutum ve kahcalğa etkisi. Yayımlanmamış doktora tezi, Adnan Menderes Üniversitesi, Aydın.

Karatay, H., \& Okur, S. (2012). Öğretmen adaylarının öyküleyici ve bilgilendirici metinleri özetleme becerileri. The Journal of Academic Social Science Studies, 5(7), 399-420.

Kelley, M.J. \& Clausen-Grace N.(2007).Comprehension shouldn't be silent Newark, USA: International Reading Association.

Kuşdemir, Y.(2014).Doğrudan ögretim modelinin ilkokul dördüncü simf ögrencilerinin okuduğunu anlama becerilerine etkisi. Yayımlanmamış doktora tezi, Gazi Üniversitesi, Ankara

Kutlu, Ö., Yıldırım, Ö., Bilican, S., \& Kumandaş, H.(2011).İlköğretim 5. sınıf öğrencilerinin okuduğunu anlamada başarılı olup-olmama durumlarının kestirilmesinde etkili olan değişkenlerin incelenmesi. Ë̆itimde ve Psikolojide Ölçme ve Değerlendirme Dergisi, 2(1), 132-139.

Mikulecky, B.S. \& Jeffries, L.(1996 ).More reading power. The United States Of America: Longman

Özçakmak, H.(2015). Türkçe ögretmeni adaylarnm not alarak dinlemede özetleme stratejilerini kullanma. Yayımlanmamıș doktora tezi, Gazi Üniversitesi, Ankara

Pilten, G. (2007). Ana fikir bulma stratejisi ögretiminin ana fikir bulma ve okudugunu anlamaya etkisi, Yayımlanmamış yüksek lisans tezi, Gazi Üniversitesi, Ankara

Reutzel, D.R., \& Cooter, R.B.(2009). The essentials of teaching childrento read: The teacher makes the difference. Boston: Pearson Education

Rose, M.S. (2001). In defence of summarization. College of The Bahamas Research Journal. 10, $29-34$.

Sever, S. (2004). Türkeçe ögretimi ve tam ögrenme. Ankara: Anı Yayınc1lik.

Sulak, S. E.(2014).Sürecsel modelle bilgilendirici metin ögretiminin okuduğunu anlama becerilerine etkisi. Yayımlanmamış doktora tezi, Gazi Üniversitesi, Ankara.

Susar Kırmızı, F., \& Akkaya, N. (2009). University students for using the summarizing strategies. Procedia Social and Behavirol Sciences. 1, 2496-2499.

Sweet, A.P.,\& Snow, C.(2002).Reconceptualizing reading comprehension. L.B. Gambrell, C.C. Block, M. Pressley (Edt.) Improving Comprehension Instruction (1. Bask1) içinde (s.17-53) San Francisco: Jossey Bass

Yılmaz, M., \& Top, M. B. (2015). İşbirlikli tartışma sorgulama (its) stratejisinin ilkokul 4. sınıf öğrencilerinin okuduğunu anlama başarılarına etkisi. Mustafa Kemal Üniversitesi Sosyal Bilimler Enstitüsü Dergisi, 12(30), 78-97.

Westby, C., Culatta, B., Lawrence, B., \& Hall-Kenyon, K. (2010).Summarizing expository texts. Topics in Language Disorders, 30(4), 275-287.

\section{Extended English Summary}

Reading skills, which are important influences in human life, can gain a wide perspective on individual academic achievement, quality communication, different cultures and ideas. Although reading tools (digital tools - printed books) vary in parallel with technical developments, reading itself retains its priority among ways of accessing information. In order to be an independent literate, it is not enough alone to have access to knowledge. It is the real thing to be able to comprehend the meaning in the text and to capture the essence, to use the obtained knowledge, to construct new ideas and ideas by means of constructing in the meaning mind. In order to be able to accomplish this, the reader's busyness with the text (/book) necessitates the use of a number of techniques and tools. The main aim of reading education is to improve the reading comprehension skills. The development of comprehension requires knowing, learning and using certain strategies, which are essentially the mainstay of being "competent readers". Starting from primary school, reading education given at many levels of education should include teaching and using the techniques of reading comprehension strategies. One of the strategies and activities used to improve the level of comprehension after reading is summarized. There are many benefits to the reader's summarization, which means that the reading is abbreviated in its sense. Summarizing, which offers positive contributions to both the teacher and the student, the student is able to recognize the main idea, control his / her understanding level and make decisions.

\section{Purpose}

The aim of the research is to examine the skills of summarizing as a component of the reading of the reading of primary school fourth graders. The questions that are searched for in the survey are: 1- What are the summaries of narrative texts of fourth grade students in primary school? 
Kuşdemir, Y., Düşünsel, C. M., \& Çelik, M. (2018). İlkokul öğrencilerinin özetleme becerilerinin incelenmesi. Journal of Human Sciences, 15(2), 893-910. doi:10.14687/jhs.v15i2.5208

2- Summarizing of narrative texts of fourth grade students in primary school,

a. According to sex;

b. According to the teacher's gender;

c. According to the status of school or teacher change;

d. According to preference of reading or writing;

e. According to the control of the written summary;

f. According to the summary writing frequency;

g. According to who has learned to summarize;

h. Does it show a meaningful difference according to the difficulty in writing the abstract?

\section{Results}

The study was carried out with the participation of 247 students in Ktrikkale province center in 2016-2017 academic year.These students liked to read both 173 and write; Of the students prefer to read only books and 16 of them prefer to write only texts. 116 women from participating students of classroom teachers; 130 of classroom teachers are male. The average scores of the students who can summarize narrative texts, write essay headlines, select important information and abbreviate in summary texts are low. According to those who prefer to read books among students, those who prefer to read and write are more likely to score important information than those who prefer to write. When $36 \%$ of fourth grade students in elementary school want to teach; $36 \%$ occasionally; $25 \%$ always write a summary. According to the results of the research, the summary of the students in the fourth grade of elementary school is controlled by $46 \%$ class teacher and $34 \%$ by parents.

\section{Discussion}

In this research, it is understood that female students are more successful in summarizing than men. When the teacher gender variable is taken into account, it is understood that the students whose class teacher is male are more successful in summarizing writing. In addition, the students' scores for determining important information when writing abstracts differed significantly according to sex and literacy preferences. Girls are more successful than men in the ability to deliver abstract information in the source text. Similarly, in the research conducted by Özçakmak (2015) with teacher candidates, it was determined that there is a significant difference in favor of females in terms of informative and narrative text summaries in the analysis of whether the gender variable makes a meaningful difference on the summarization skills of the students. When the results are evaluated, summarization is proved to be more successful as a comprehension strategy that girls read. $74 \%$ of the students who participated in the survey stated that they learned from their teachers to write summaries. When the summary text title writing scores of the students were examined, it was determined that the students who learned to write summaries from their parents or friends were higher than the general average of the title writing averages. It was found that the students who learned to write abstracts from their teachers or other people in the school had lower average writing scores than the average. The created text is the plain text of the title text and its main idea is described directly in the simplest form. Especially in the summary writing process, the summary text of the title of the source text must be preserved exactly. Within the observation system of "finding the heading in the reading material" and "finding the main idea to be explained in the material" regarding the summarization strategy in the study to determine the effects of the learning strategies and the writing skills of Belet (2005) it is achieved as a result of relatively less earning. Çıkrikçı (2004) investigated which units in the text and what strategies were used in the process of converting a particular text structure into a summary text structure. Fifth grade students seem to have less divergence in the content integrity of the text because they use the direct quoting and quoting strategies most often in the summarizing act, and students use the direct quoting strategy extensively. The fact that different research results are similar to each other generally reinforces the idea that students are inadequate in writing essays. Different studies can be done to review the summarization process of expsitory texts. In addition, longitudinal investigations involving both primary and secondary school students can examine the factors that influence the summarization of reading and writing skills used together. Specific research can also be designed to examine the appropriateness of reading, understanding and summarizing skills of texts in Turkish books used in school. 